\title{
Rebuilding the Hungarian-Romanian Border Zone as a Learning Region
}

\author{
Zoltan Zakota \\ Partium Christian University, Romania
}

\begin{abstract}
Although there is no straightforward definition for the concept of learning regions, it is still subject of a worldwide intensive research. As a general approach, we could affirm that it embodies the territorial application of the knowledge economy in its evolution. One also have to notice that the study of these entities constitutes a very dynamic subfield of regional studies. In this sense, our paper applies some of the results obtained in this field of research to the Hungarian-Romanian border zone. This region, although divided since almost a century by a state frontier, still inherits several features from the pre-WWI period. On the other hand, after the fall of communism, old ties were rebound, especially in the form of trans-frontier co-operation. Both halves of the area do benefit from a quite well developed infrastructure, industrial and tertiary facilities, as well as important educational and cultural institutions. There exists a quite solid network of big and small towns, each of them with its own agglomeration area, trying to rebind the old lines of influence. In our study, we also examine the possibilities of using these advantages combined with the post-1989 experience in transforming this area into a learning region.
\end{abstract}

Keywords: Hungarian-Romanian border zone, learning regions, regional studies, trans-frontier co-operation

JEL classification: M4, R1 1

\section{Introduction}

The concepts of learning communities, cities, and/or regions are relatively new, therefore we cannot find any single valid definition. The concept draws especially on theories about innovation and systems that promote innovation, so there is an explicit commitment to placing innovation and learning at the core of development, sustaining economic activity through various combinations of lifelong learning, innovation and creative uses of information and communication technologies.

Changes in learning have to be taken into consideration, because they are of highest importance at both individual and institutional levels. The acquisition of knowledge, skills and understanding by individual people, whether formally or informally, is profoundly influenced by these changes. Nowadays these often refers to lifelong learning, not just initial schooling and training.

When mentioning the benefits of learning we shall look to different beneficiaries located at different levels:

- individuals gain through improved wages and employment opportunities;

- society benefits by having a flexible and technologically up-to-date workforce;

- learning is a powerful means for competitiveness in a global economy;

- commitment on the part of all partners (public authorities, private enterprises, education and R+D institutions, NGOs, key individuals) to place learning and knowledge dissemination at the centre of development; 
- learning by experience is highly effective when it becomes everyday practice.

Nowadays, there are several learning regions in Europe, which could serve as examples for the potential Central and Eastern European ones. Among them, we can mention Jena, in Germany, as an example of successful transition from communism to capitalism or Poitiers, in neighbouring France, for the way in which a predominantly rural area has set its sights on development through ICT and a highly skilled work force. We can find an interesting trans-frontier co-operation in the Oresund region which links Copenhagen in Denmark with Malmoe in Sweden, offering a high concentration of research facilities, first-class educational institutions and technological know-how in Scandinavia. The Andalusia region of Spain succeeded in shifting from a historical melting pot and tourist attraction through investments in communications, technology and research, combined with the presence of well-established universities an attraction point for new companies and enterprises. The Kent Thames-side area, east of London, is a good example for vitality generated by the proximity of partners, frequent interaction and the easy, informal exchange of information.

\section{Methodology}

In our study, I started from the analysis of the region, by taking into consideration not only its physical and geographical, but also its economic and cultural characteristics. One of the prevalent viewpoints was the educational one, i.e. the number, character and size of the educational institutions in the region, esp. in respect higher education.

I based my study and, of course, my conclusions mostly on the results of the former Hungarian-Romanian trans-frontier co-operation project, which were, against all critics, a considerable success. Of significant importance were also my informal discussions with persons in key positions (administration, politics, education, culture), as well as leaders and participants of cross-border co-operation projects. I also tried not to leave out of consideration the cultural and historical specificities of the Hungarian-Romanian border zone, which still are sources of several wounds, offences and prejudices.

\section{Result}

\section{Characteristics of the Hungarian-Romanian Border Region}

The target area consists of eight counties along the Hungarian-Romanian border, four on each side of it. The total length of the border is $448 \mathrm{~km}$, from which $415.8 \mathrm{~km}$ land and $32.2 \mathrm{~km}$ rivers. The total population of the area surpasses 4 million people, living on a total surface summarizing $50.454 \mathrm{~km}^{2}$, from which $43.7 \%$ is located on the Hungarian and $56.3 \%$ on the Romanian side. The fact that 235 ha are protected natural areas (natural parks and landscape protected areas), meaning about $4.7 \%$ of its total territory, could be of some significance when thinking on the future of the area, as a potential extension of the European Green Belt. Zakota (2016). The territory consists of mostly agricultural land, but due to several economic, social, demographic and legal factors not all of it is in permanent use.

The eight counties are, as they follow, from North to South: Szabolcs-SzatmárBereg, Hajdú-Bihar, Békés and Csongrád on the Hungarian side, respectively Satu Mare, Bihor, Arad and Timiș on the Romanian side. The Western part of Szatmár and Satu Mare once were a part of the former Szatmár County in Hungary, while the Western part of Hajdú-Bihar and the actual Bihor once formed the Hungarian Bihar 
County. The links once existed between the towns and villages on the two sides of the border can still be seen and, despite the very strict regulation that existed in the communist era, they are continuously strengthening since its fall. Most of the actual county centres (Satu Mare, Oradea, Arad, Timișoara and Szeged) have had this status also before World War I, being real regional gravity centres, while the others (Nyíregyháza, Békéscsaba and, in some degree, Debrecen too) became regional centres just after the new borders were drawn. When enumerating the main activity fields in each of them, we have on the Hungarian side:

- Nyíregyháza: tourism, electronics, cutting edge technologies, logistics;

- Debrecen: leisure and spa tourism, pharmaceutical and food industry, higher education, R\&D;

- Békéscsaba: food industry, transport;

- Szeged: culture, tourism, higher education, R\&D, logistics;

respectively on the Romanian side:

- Satu Mare: machine and equipment industry, furniture and light industry, logistics, spa;

- Oradea: trade, third sector, tourism, spa, light industry, food industry, chemical industry, furniture industry, higher education;

- Arad: higher education, logistics, machine and equipment industry, rail cars, food and textile industry;

- Timişoara: electronics, robotics, machine and equipment industry, light industry, logistics, cultural tourism, higher education, R\&D.

\section{The Influence of the County Centres}

There are attempts to evaluate the influence of the county centres e.g. by their attraction force, by estimating the length of the border segment over which this Influence could be exerted.

\section{Table 1}

Length of the border segments under the Influence of county centres, in a hypothetical "no border" situation

\begin{tabular}{|c|c|c|}
\hline & & Length of border segment $(\mathrm{km})$ \\
\hline \multirow{3}{*}{ 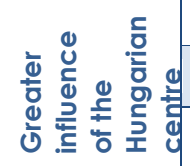 } & Debrecen & 57.6 \\
\hline & Békéscsaba & 26.1 \\
\hline & Szeged & 57.7 \\
\hline \multirow{3}{*}{ 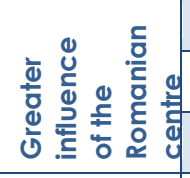 } & Satu Mare & 52.9 \\
\hline & Oradea & 77 \\
\hline & Arad & 64.4 \\
\hline \multirow{5}{*}{ 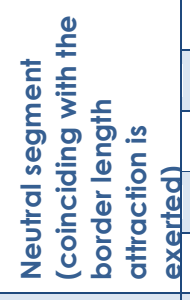 } & Debrecen - Nyíregyh. - Satu M. & 33 \\
\hline & Debrecen - Nagyvárad & 4.1 \\
\hline & Békéscsaba - Nagyvárad & 30.9 \\
\hline & Békéscsaba - Arad & 12.2 \\
\hline & Szeged - Arad & 8.4 \\
\hline Hungarian & $33.3 \%$ & 141.4 \\
\hline Romanian & $45.8 \%$ & 194.3 \\
\hline Neutral & $20.9 \%$ & 88.6 \\
\hline
\end{tabular}

Source: Szilágyi (2013) 
Table 1 shows the figures obtained for a hypothetical "no border" situation, the case when Romania would be accepted into the Schengen-area, i.e. free movement of people and goods over the border.

As we can notice, the Romanian centres could exert a higher $(45.8 \%, 194.3 \mathrm{~km})$, while the Hungarian part would have a slightly lower influence $(33.3 \%, 141.4 \mathrm{~km})$. The rest of the settlements beside the actual border would be "neutral" (20.9\%, $88.6 \mathrm{~km})$. The case of Timişoara is quite different, the city being located far more Southworth from the border.

\section{Higher Education, Research and Development}

All eight county centres are playing some role in higher education, each of them having at least one relevant institution, but there are significant differences between them regarding national regulations, structure or size, as shown in table 2.

Table 2

Number of Students by County of Instruction

\begin{tabular}{llllll}
\hline Hungary & $\begin{array}{l}\text { Szabolcs-Szatmár- } \\
\text { Bereg }\end{array}$ & Hajdú-Bihar & Békés & Csongrád & Total \\
\hline \multirow{2}{*}{ Romania } & 2477 & 20018 & 474 & 16901 & 39870 \\
\hline & Satu Mare & Bihor & Arad & Timiș & Total \\
\hline & 1291 & 16404 & 12052 & 39898 & 69645 \\
\hline
\end{tabular}

Sources: Hungarian Central Statistical Office (2016), Romanian National Institute of Statistics (2017)

Due to the highly centralised Hungarian system there are less universities on that side and practically no private institutions. One may notice the overwhelming role played by Timișoara (Timiș) as the biggest higher education centre in the whole region, followed by Debrecen (Hajdú-Bihar), Szeged (Csongrád), Oradea (Bihor) and Arad (Arad) in the middle-rank, the line being closed by Nyíregyháza (SzabolcsSzatmár-Bereg), Satu Mare (Satu Mare) and Békéscsaba (Békés). The last two centres do not even have autonomous institutions, just local branches of some bigger universities.

In relation R\&D, the region looks somewhat different, as it is illustrated by table 3 showing the total number of R\&D-sector employees in the year of 2015. Evidently, these figures are far from being sufficient when evaluating R\&D but they may illustrate the leading role the three major university-centres, Debrecen, Szeged and Timișoara do have in the R\&D-sector. This may happen also because of their better infrastructure and openness to attract foreign capital, especially in high-tech domains.

Table 3

Number of R\&D Employees by County

\begin{tabular}{llllll}
\hline Hungary & $\begin{array}{l}\text { Szabolcs-Szatmár- } \\
\text { Bereg }\end{array}$ & Hajdú-Bihar & Békés & Csongrád & Total \\
\hline \multirow{2}{*}{ Romania } & 532 & 3873 & 349 & 4580 & 9334 \\
\hline & Satu Mare & Bihor & Arad & Timiș & Total \\
\hline & 27 & 160 & 830 & 2748 & 3765 \\
\hline
\end{tabular}

Sources: Hungarian Central Statistical Office (2016), Romanian National Institute of Statistics (2017) 


\section{The Hungary-Romania Cross-Border Co-operation Programme}

As stated in the official documents: "[t] he general objective of the programme is to bring the different actors - people, economic actors and communities - closer to each other, in order to better exploit opportunities offered by the joint development of the border area." (Hungary-Romania Cross-Border Co-operation Programme 2007-2013, Objectives and priorities) The total amount of the funds invested into the program was 248 million EUR, divided between the main actors, as shown in table 4.

Table 4

HU-RO CBC Program Funding

\begin{tabular}{llll}
\hline & EU Budget & National Budget & Own Sources \\
\hline Hungary & $85 \%$ & $10 \%$ & $5 \%$ \\
\hline Romania & $85 \%$ & $13 \%$ & $2 \%$ \\
\hline
\end{tabular}

Source: Hungary-Romania Cross-Border Co-operation Programme 2007-2013, Overview

If we analyse the distribution of lead partners by the registration county of project partners we have to conclude that, in most cases, lead partners are selecting their project partners from the neighbouring county, as shown in table 5, the only exception being Békés County with its two neighbors: Arad and Bihor. As we also can notice, the Hungarian side is more active than the Romanian one. The only exception is Bihor County, surpassing even Timiș. We may confidently suppose that, on the Romanian side, there is a positive correlation between having a considerable Hungarian population and initiating cross-border projects.

Table 5

Distribution of Lead Partners by the Registration County

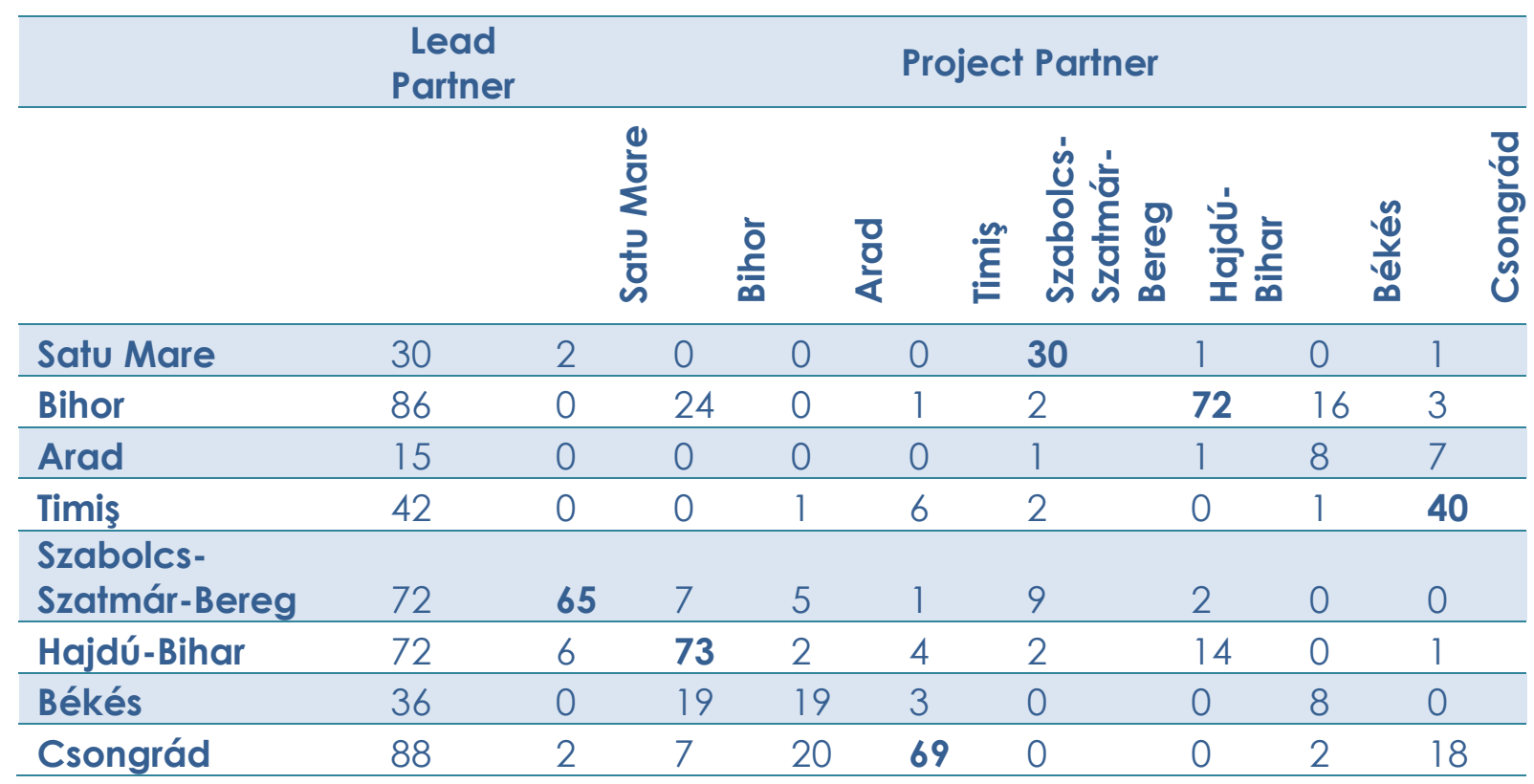

Source: Hungary-Romania Cross-Border Co-operation Programme 2007-2013, Financed projects

The program had two main priorities, divided into several key areas, as shown in the left column of table 6. (Hungary-Romania Cross-Border Co-operation Programme 2007-2013, Objectives and priorities). The table synthesises the distribution of trans- 
frontier projects and their funding by priorities and key areas of intervention. As one can notice, a considerable number of projects were submitted in the fields of R\&D and innovation (13\%), labor market and education (17\%), respectively protection of the environment (14\%). The distribution of funds allocated to the cross-border projects does not reflect the distribution of their number, but we have to take into consideration that an appreciable number of applicants came from the realm of education and the not-for-profit sphere.

\section{Table 6}

Distribution of trans-frontier projects and their funding by priorities and key areas of intervention

\begin{tabular}{|c|c|c|}
\hline & $\begin{array}{l}\text { Number and } \\
\text { Distribution of } \\
\text { Projects by Key } \\
\text { Areas of } \\
\text { Intervention }\end{array}$ & $\begin{array}{l}\text { Funding and } \\
\text { Distribution of Projects } \\
\text { by Key Areas of } \\
\text { Intervention (EUR) }\end{array}$ \\
\hline $\begin{array}{l}\text { Priority 1: Improve the key conditions of } \\
\text { joint, sustainable development of the } \\
\text { cooperation area }\end{array}$ & $64 ; 32 \%$ & $45,575,967.84 ; 53 \%$ \\
\hline $\begin{array}{l}\text { 1.1: Improvement of cross-border } \\
\text { transport facilities }\end{array}$ & $20 ; 10 \%$ & $28,413,193.22 ; 33 \%$ \\
\hline $\begin{array}{l}\text { 1.2: Improvement of cross-border } \\
\text { communication }\end{array}$ & $16 ; 8 \%$ & $5,781,762.83 ; 7 \%$ \\
\hline 1.3: Protection of the environment & $28 ; 14 \%$ & $11,381,041.79 ; 13 \%$ \\
\hline $\begin{array}{l}\text { Priority 2: Strengthen social and } \\
\text { economic cohesion of the border area }\end{array}$ & $137 ; 66 \%$ & $40,979,093.21 ; 47 \%$ \\
\hline $\begin{array}{l}\text { 2.1: Support for cross-border business } \\
\text { cooperation }\end{array}$ & $32 ; 16 \%$ & $12,378,976.25 ; 14 \%$ \\
\hline $\begin{array}{l}\text { 2.2: Promotion of co-operation in the } \\
\text { field of } R+D \text { and innovation }\end{array}$ & $26 ; 13 \%$ & $8,242,370.99 ; 9 \%$ \\
\hline $\begin{array}{l}\text { 2.3: Cooperation in the labor market } \\
\text { and education - joint development of } \\
\text { skills and knowledge }\end{array}$ & $34 ; 17 \%$ & $4,829,402.56 ; 6 \%$ \\
\hline $\begin{array}{l}\text { 2.4: Health care and prevention of } \\
\text { common threat }\end{array}$ & $13 ; 6 \%$ & $11,325,906.24 ; 13 \%$ \\
\hline $\begin{array}{l}\text { 2.5: Cooperation between } \\
\text { communities }\end{array}$ & $32 ; 16 \%$ & $4,202,437.17 ; 5 \%$ \\
\hline $\begin{array}{l}\text { Source: Hungary-Romania Cross-Border Ca } \\
\text { projects }\end{array}$ & eration Prog & 2007-2013, Finc \\
\hline
\end{tabular}

\section{Conclusion}

The Hungarian-Romanian border region has some specific characteristics which constitutes a solid base to further development. The common past, the existing crossborder ties and the experience accumulated through the former cross-border projects constitute solid arguments in favour of future cooperation. Due to the existing infrastructure, educational framework and investments in the field of R\&D, the region could develop into a veritable learning region. 


\section{References}

1. Hungary-Romania Cross-Border Co-operation Programme 2007-2013, Financed projects, available at: http://www.huro-cbc.eu/en/financed_projects/ (16 April 2017)

2. Hungary-Romania Cross-Border Co-operation Programme 2007-2013, Objectives and priorities, available at: http://www.huro-cbc.eu/en/objectives_and_priorities/ (16 April 2017)

3. Hungary-Romania Cross-Border Co-operation Programme 2007-2013, Overview, available at: http://www.huro-cbc.eu/en/overview/ (16 April 2017)

4. Romanian National Institute of Statistics (2017), „Romanian Statistical Yearbook - time series (CD-ROM)", available at: http://www.insse.ro/cms/en/content/romanianstatistical-yearbook-time-series-cd-rom (16 April 2017)

5. Szilágyi, F. (2013), „A nagyvárosi vonzáskörzetek áttekintése a magyar-román határsávban" ("Urban Attraction-centres in the Hungarian-Romanian Border Region"), in Szilágyi F., Zakota Z. (Eds.), Partium - társadalom- és térszerkezet (The Partium Region - Social and Spatial Structure), Dokumentum, Oradea, pp. 85-102.

6. Zakota Z., Zakota T. Z. (2016), "On the Possibility of Extending the European Green Belt to the Hungarian-Romanian Border Region", in: Greenways and Landscapes in Change - Proceedings of 5th Fábos Conference on Landscape and Greenway Planning Budapest, pp. 539-546.

\section{About the author}

Zoltan Zakota is lecturer at the Partium Christian University, in Oradea, Romania. He is a co-founder of the departments of Management and that of Finances. At present he is lecturing computer science, application of informatics in economics and society, econometrics, European Economics. His main fields of interest are information society, knowledge-based society, the effect of communication and information technologies on society and economics, regional development. Actually he is involved in two main projects: one of them dealing with the effects of transfrontier cooperation on regional development, and the other concerning money laundering. Author can be contacted at zzakota@gmail.com. 